\title{
Factors Influencing the Choices of Accounting Policies in Small and Medium Enterprises in Vietnam
}

\author{
Cuong Duc PHAM${ }^{1}$, Trong Van PHI $^{2}$
}

Received: August 01, 2020 Revised: September 06, 2020 Accepted: September 12, 2020

\begin{abstract}
Accounting policies are principles and practices by which an entity uses to recognize, measure and report economic transactions. Improper application of accounting policies can lead to misrepresentation of firms' financial position and performance which consequently results in incorrect accounting information to the users. This paper aims to investigate the factors influencing the choices of accounting policies in small and medium enterprises (SMEs) in Vietnam by reviewing relevant literature to build a research model. The research model comprises of one dependent variable that is income-decreasing accounting procedures and six independent variables namely the firm size, financial leverage, incentives, auditor, accountants, and tax policies. After this, the authors collected primary data from more than 200 questionnaires sent to directors and chief accountants of the SMEs for the period 2018 to 2019. We then used Ordinary Least Squares regression method (OLS) to analyze the data. The results showed that four factors influenced selection of accounting policies in which auditors are associated with income-increasing accounting policies; and there are three factors associated with income-decreasing accounting policies which are, company size, tax and accountant. Especially, the research results indicate that company size has a significant influence on the selection of accounting policies in the SMEs. Based on the results, we propose instructive suggestions for regulators and lawmakers improve choices of accounting policies in the SMEs.
\end{abstract}

Keywords: Accounting Policies, Accounting Principles, Policy Choices, SMEs, Vietnam

JEL Classification Code: M41, G32, D82

\section{Introduction}

According to the financial accounting theory, companies choose their appropriate accounting methods in order to provide a true and fair view of their business activities. These choices are captured in the accounting policies of the entities and are the foundation of drawing up and interpreting their financial statements, i.e. financial position, performance and cash-flows of the period. Therefore, companies make

${ }^{1}$ First Author. Associate Professor, Head of Accounting Principles Department, School of Accounting and Auditing, National Economics University, Vietnam. Email: cuongpd@neu.edu.vn

${ }^{2}$ Corresponding Author. Lecturer, School of Accounting and Auditing, National Economics University, Vietnam [Postal Address: 207 Giai Phong, Hai Ba Trung, Hanoi, 113068, Vietnam]

Email: trongpvketoan@neu.edu.vn

(c) Copyright: The Author(s)

This is an Open Access article distributed under the terms of the Creative Commons Attribution Non-Commercial License (https://creativecommons.org/licenses/by-nc/4.0/) which permits unrestricted non-commercial use, distribution, and reproduction in any medium, provided the original work is properly cited. deliberated choices on alternative accounting methods, often labeled in the literature as professional judgment.

In an overview of one of the previous studies, we found that the managers choose accounting policies to increase or decrease the reported income to serve their own needs (Beattie, Stephen, David, Brian, Stuart, Dylan, and Turner, 1994; Bowen and Shores, 1995; Astami and Tower, 2006). It is obvious that the previous studies tend to focus on firms in developed countries (Inoue and Thomas, 1996; Cullinan, 1999) and countries in the Asia-Pacific region (Rahman and Scapens, 1988; Tawfik, 2015; Astami and Tower, 2009). There have not been many studies on management policy selection of managers in the context of Vietnam, especially for the small and medium enterprises (SMEs).

In addition, the research results about developed countries and the Asia-Pacific region may not be relevant to Vietnam due to certain differences in the environment resulting from economic position, culture, political and social system. Thus, the results of this study are expected to be important for managers of SMEs in Vietnam in determining the flexibility of accounting practices as well as explanations needed to 
support users of financial statements. In addition, this study is also critical for investors in Vietnam to analyze financial statements when making investment decisions.

\section{Literature Review}

Accounting policies are rules, principles and practices by which an entity uses to recognize, measure and report economic transactions and events. Application of accounting policies enables an economic entity to disclose its financial position and performance (Okpala, 2016). The accounting policies applied by a firm should specify how transactions and events were measured in the financial statements. A company is not only required to disclose all of its material accounting policies as notes to the financial reports but that the application must be consistent. This information helps users to clearly understand a company's financial performance and the position of the company. Accounting policies applied must be appropriate to the opinion of management to the circumstances and best suited to present fairly and reasonably its financial result and position. Any specific company needs to adopt accounting policy so that its financial statements gives a true and fair view of its operations (Collings, 2010).

There have been many researches about the factors affecting the choice of accounting policies in firms. In the area of of choosing accounting polices, DeAngelo, DeAngelo, and Skinner (1994) studied accounting choices in 76 NYSE firms with persistent losses and dividend reductions. The authors found that managers' accounting choices primarily reflect their firms' financial difficulties, rather than attempts to inflate income. Bowen and Shores (1995) studied the ongoing implicit claims between a firm and its customers, suppliers, employees, and short-term creditors to create incentives for management to choose long-run income-increasing accounting methods. Variables selected to proxy for the extent to which a firm depends on these implicit claims are found to be significant in explaining cross-sectional variation in inventory and depreciation methods.

In continuation, Cullinan (1999) proposed that international trading activities may create incentives for firms to choose income increasing accounting policies. This proposition was tested by examining the depreciation choices of a sample of Canadian firms. Results suggest that importers were more likely to choose income increasing accounting methods than non-importers, while exporting was not found to be related to this accounting choice. These diverging results may be caused by the declining value of the Canadian dollar (relative to the US dollar), which tends to benefit exporters, but is detrimental to the importers.

Astami and Tower (2006) studied the relationship between firm-specific variables and management's choice of accounting policies by examining four key accountingpolicy disclosures in the 2000/2001 annual reports of 442 listed companies in the Asia Pacific region. The dependent variable was the composite measure for the income increasing (decreasing) accounting-policy choice tendency. The results showed that firm-specific variables linked to Costly Contracting Theory partially explains management's choice of accounting policies. Companies that pursue income-increasing accounting techniques are characterized by lower financial leverage, lower level of ownership concentration, and higher investment opportunity sets. This finding hold true when country and industry control variables are not considered. When the control variables are included, the CCT variables are less a factor and instead country of reporting provides the strongest explanation for company managers' choice of accounting policies. Indonesian companies generally utilize the most income-decreasing accounting techniques.

Tzovas (2006) investigated the factors that influenced the accounting policy decisions of firms operating in Greece. Emphasis was given to managers' perceptions regarding the impact that accounting figures have upon the decisionmaking and opinions of firms' stakeholders. According to the participants in the survey, accounting figures influence firms' stakeholders perceptions and decision-making, and firms pursure profit-related objectives that may not coincide with the objective of minimization of firm tax obligation. Fekete, Damagum, Mustata, Matis and Popa (2010) investigated the accounting policy choices of SMEs, particularly those related to the evaluation methods for Romanian SEMs. The results show that while taxation seems to remain the strongest influencing factor, the weakest happens to be the true and fair view (TFV) consideration.

For the factors affecting the choice of accounting policies in firms, there have been numerous studies which could be summarized as follows: For the first factor, that is firm size, Watts and Zimmerman (1986) stated that the political costs of big companies are always higher than that of small companies. Managers of large companies may prefer the accounting methods that delay the reporting of income to reduce political costs (Missonier-Piera, 2004). This is consistent with studies of Hagerman and Zmijewski (1979, 1981); Kenneth and Michael (1992); Inoue and Thomas (1996) for Japan; Waweru, Ntui and Mangena (2011) in Tanzanian; Shaheen (2012) for Kuwait; Kim and Cho (2020). However, many researchers like Missonier-Piera (2004); Tawfik (2015); Astami and Tower (2006) found that there is no correlation between enterprise size and selection of accounting policies to increase or decrease income in Switzerland, Saudi Arabia and the Asia-Pacific region.

In one different aspect, that is leverage, various authors (for instance Kenneth and Michael, 1992; Inoue and Thomas, 1996; Cotter, 1999) evidence that the degree of financial 
leverage has a positive effect on the choices of accounting policies to increase income. Bowen and Shores (1995) explain that to ensure the creditworthiness of loans or to improve the financial flexibility of companies, managers try to use accounting methods to increase income, which allows them to publish favorable financial statements. This result is consistent with research findings of Watts and Zimmerman (1986); Cullinan and Knoblett (1994); and Waweru, Ntui and Mangena (2011). Differently, Missonier-Piera (2004) in research about Swiss context pointed out that financial leverage has no impact on the choices of accounting policies to increase income in the context of Sweden. Some other scholars have same findings, for example, Tawfik (2015) for Saudi Arabia; Aitken and Loftus (2009) for Australia.

In another vein study, incentive plans, Watts and Zimmerman (1978) and Cotter (1999) report that firms' managers have the incentive to use accounting policies to increase accounting income if part of their income is derived from the incentive plan. However, in the same research in the ontext of Vietnam, Nguyen and Nguyen (2014) found that the incentive policies for managers have no impact on the selection of accounting policies in small and medium enterprises in Vietnam. For the effect of auditing factor on choosing accounting policies, DeAngelo (1981) argued that larger audit firms have higher audit quality, so companies audited by large audit firms are less likely to change their accounting policies regardless whether these changes is done to increase or decrease income. Takada and Muramiya (2013) provided that when changing accounting policies to reduce income can improve the financial health of a company, auditors may pay less attention on this and focus more on changes that increase income. Some other authors found that large audit firms are effective in restraining changes in accounting policies that increase income (Astuti, Fachrurrozie, Amal, Zahra, 2019) also found similar results.

Also, there have been research about the effect of tax policies on choosing accounting policies which results from the differences between accounting profits and taxable income. Sutton (1988) argued that taxes played an important role in business development. The tax forces businesses to reduce taxable profits by increasing inventory costs and investing in new assets. The difference is due to different regulations on measurement, revenue recognition, income and expenses in accounting and taxes. It is obvious that, in Vietnam, there is a close relationship between accounting and taxation, tax laws strongly intervene in the accounting policies in terms of measurement, recording and disclosure of financial statements. Accounting principles are imposed to determine taxable profit. This close relationship shows that, when an administrator takes action to manage accounting profits, the taxable profits are affected to some extent. In other words, the administrator can take earning management to save income tax when the opportunity arises.
In the context of Vietnam, Nguyen and Nguyen (2014) when studying the factors affecting the selection of accounting policies in Vietnamese firms, found that tax is one of the significant factors which affected managers' behavior of choosing the type of accounting policies. And last, Do, Nguyen, Nguyen, Ha, and Le (2020), in their study about accountants' commitment with Vietnamese FDI enterprises, belive that the knowledge and experience level of accountants affect the ability to choose suitable accounting policies to maximize the benefits of the business. If the accountant is able to apply accounting policies effectively, it will help the business administrator to achieve the set goals.

\section{Theoretical Framework}

\subsection{Agency Theory}

The agency theory (Jensen and Meckling, 1976) also called the theory of authorization focuses on the relationship between the owner (called the principal) and the authorized party (called the agent). The agency inevitably creates a conflict between the principal party and the agent, between shareholders and creditors. To resolve these contradictions, the manager tends to manipulate the accounting data on financial transactions to harmonize the interests of the parties. The agency theory is specifically used to explain the concurrent CEO position of the Chairman, the size of the Board, the independence of the Board of Directors, number of Board of Director meetings, number of Supervisory Board members, type of auditing company, state-owned percentage, and ownership of management affecting the earning quality.

\subsection{Stakeholder Theory}

Stakeholder theory focusses on management strategy and ethics which was first introduced by (Freeman, 1984). The central idea of this theory is that the success of an organization depends on the relationship between the manager and stakeholders such as investors, creditors, workers, customers, suppliers, state and other entities involved in achieving the enterprise's goals. There are quite a few studies that apply stakeholder theory to justify the results of this research. The stakeholder theory proposes that a company which has a large and diverse Board of Directors is appropriate and it has many advantages for linking the components. In addition to agency theory, the stakeholder theory is also combined to explain how the factors of the Board of Directors affect the earning quality.

On the other hand, the management-based branch argues that organization will react to society through the power of their stakeholders to influence corporate governance. Based on this perspective, organizations will provide information 
that target the interests and expectations of specific groups or key stakeholders related to the organization. As a result, corporate information disclosure will be used as a strategy to maintain the support of key stakeholders (Islam \& Deegan, 2010). According to the stakeholders' theory, organizations aim to balance the expectations of all stakeholder through their activities. Organizations need to take care of all the stakeholders and should ensure that they are happy. Managers should consider and maintain the expectations of all stakeholder groups when making decisions about social responsibility. Stakeholders theory is used in this study to explain what motivates enterprises to practice SR publication.

\subsection{Signalling Theory}

Signal theory was introduced by Spence (1973). While studying the labor market, he had argued that hiring workers is an uncertain decision because they do not know the true competence of workers. Ross (1977) argues that the inherent contradictions of shareholders and managers cause the manager to focus on providing central signals and meeting the basic information needs of users. In the financial market, the principal relationship between the shareholder and the manager is expressed by return on investment, the investor makes economic decisions based on profitability indicators.

\subsection{Capital Market Efficiency}

Profits are of great interest to financial market participants, especially investors and analysts. Recent studies provide evidence that reported profits are one of the most important information from a company (Francis, Maydew and Sparks, 2004), as they are a good indicator of future cash flows and also the fact that there is more information about a company's economic performance than just the cash flow (Dechow, 1994). Francis, Maydew and Sparks (2004) while examining the relationship between several attributes of profit and cost of equity in the United States found that the properties of profit based on accounting (cumulative quality, sustainability, predictability and stability) are more cost effective than market-based attributes (relevance of value, timeliness and prudence) and cumulative quality attributes have the highest value. In a study by Bhattacharya, Daouk, $\&$ Welker (2003) found that the increase in profits, is defined as an aggregate measure of the positive level of income, avoiding losses and the stability of profits, This is related to an increase in the cost of equity and a decrease in transaction volume. In the US market, there have been some studies such as by Bitner and Dolan (1996), Rountree, Weston, and Allayannis (2008), they studied the relationship of EQ with corporate valuation (measured by Tobin'Q), and meanwhile, Bitner and Dolan (1996) examined the relationship between profit stability and FV.

\section{Research Methodology}

\subsection{Research Model and Hypotheses}

Based on the overview of prior researches on the factors affecting the choices of accounting policies, research gaps were identified and hypotheses were developed to predict the factors influencing the selection of accounting policies. The conceptual framework is displayed as follows: (See Figure 1).

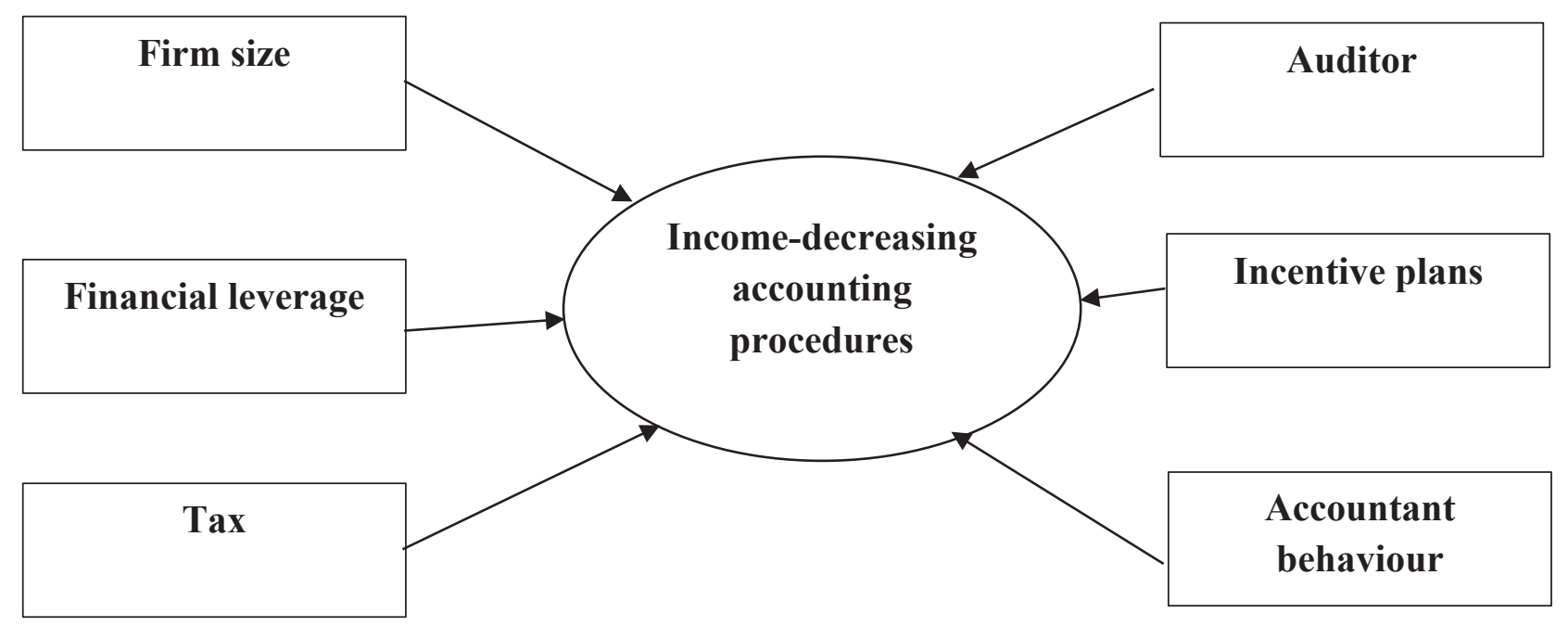

Figure 1: The proposed research model 
This was a quantitative study, using Ordinary Least Squares regression method (OLS). Based on the obtained results after analysis, the author discussed the results and provided recommendations and suggestions to subjects such as business executives, investors and the state agencies on the ability to use the accounting information on the financial statements of SMEs for the selection of accounting policies to help them make business and investment decisions.

Raffournier (1995) studying SMEs in Switzerland noted the existence of a significant association between firm size and disclosure. If firm size plays an important role in determining the extent of disclosure by companies, SMEs are likely to reveal less information and also choose accounting policies and disclosures based on their individual performances, capacity and the environmental characteristics they face including the tax systems.

In developing countries like Vietnam, large companies are considered as exploiting the countries' resources and are likely to be strictly controlled, thereby; reporting of substantial income may make companies suffer significant political consequences. However, in Vietnam and most other countries in the Asia-Pacific, large companies are politically connected (Waweru, Ntui \& Mangena, 2011). It means that in the politically connected companies, political costs associated with reporting huge income may not be an issue because managers are protected by politicians who have influences on those they are connected to. Moreover, since the governments of developing countries like Vietnam are encouraging companies to participate in economic development, state intervention may be unrealistic. Therefore, the first hypothesis is proposed as follows:

$\mathrm{H}_{1}:$ The larger the company size, the more likely it is that managers will choose accounting policies to reduce reported income.

In the context of Vietnam, companies often rely on bond holders and banks to secure their finances. Due to the dependence on debt, managers have incentives to choose accounting policies to increase reported income to ensure that the companies comply with debt obligations imposed by bond holders and banks as well as avoiding renegotiation costs (Inoue and Thomas, 1996). Thus, the second hypothesis is proposed as follows:

$\boldsymbol{H}_{2}$ : In Firms with high debt to equity ratios (financial leverage), managers are more likely to select incomeincreasing accounting procedures

If a management incentive plan has an incentive plan related to accounting income, managers have motivation to use accounting principles to increase accounting profits as part of their income from such an incentive plan. Thus, the next hypothesis is as follows:

$\boldsymbol{H}_{3}$ : If enterprises have incentive plans, managers are more likely to choose accounting policies to increase reported income

Takada and Muramiya (2013) suggest that changing the accounting policy to reduce profitability can help improve a company's financial health, in this scenario, auditors may focus less on such companies and are likely to focus more on companies who work on their accounting policies to increase profits. Nelson et al. (2002) demonstrate that auditors are less concerned with customers seeking to reduce profits than those seeking to increase profits. Thus, the next hypothesis is displayed as follows:

$\boldsymbol{H}_{4}:$ Audited companies are more likely to choose a profitreducing accounting policy.

Sutton (1988) argued that taxes played an important role in business development. The tax forces businesses to reduce taxable profits by increasing inventory costs and investing in new assets. The difference is due to different regulations on measurement, revenue recognition, income and expenses in accounting and taxes. It is obvious that, in Vietnam, there is a close relationship between accounting and taxation, tax laws strongly intervene in the accounting practices for measurement, recoding and disclosure of financial statements. Accounting principles are imposed to determine taxable profit, which means that the accounting method is used to determine the taxable profits. This close relationship shows that, when an administrator takes action to manage accounting profits, to some extent taxable profits are affected. In other words, the administrator can take earning management to save income tax when the opportunity arises. For Vietnam context, Nguyen and Nguyen (2014) when studying the factors affecting the selection of accounting policies in Vietnamese firms also report that tax is one factor which significantly affects managers' behavior of choosing accounting policies. Thus, the next hypothesis is displayed as follows:

$\boldsymbol{H}_{5}:$ To avoid paying taxes, enterprises choose accounting policies to reduce profits.

$\boldsymbol{H}_{6}$ : Highly qualified accountants will choose accounting policies to reduce profits. 


\subsection{Research Method}

The author used the regression model to test the hypotheses about the factors influencing the selection of accounting policies in SMEs in Hanoi, the multivariate regression i ass follows:

$$
\mathrm{Y}=\beta_{0}+\beta_{1} \mathrm{X}_{1}+\beta_{1} \mathrm{X}_{2} \ldots+\beta \mathrm{n} \mathrm{X}_{\mathrm{n}}+\varepsilon
$$

In which:

$\mathrm{Y}$ : Dependent variables

$\mathrm{X}_{1}, \mathrm{X}_{2} \ldots \mathrm{X}_{\mathrm{n}}$ : Independents variables

$\varepsilon$ : error (the difference between actual value and predicted value)

After selecting variables to be included in the regression analysis, the author used the F-test to assess the appropriateness of the linear regression model; used t-test to evaluate the significance of regression coefficients of independent variables and used the variance inflation factor - VIF to identify collinearity among independent variables. There is a collinearity phenomenon among independent variables if the value of VIF is greater than 10. Accordingly, the regression model selected for analysis has the highest adjusted coefficient of determination.

\subsection{Research Model}

Based on the development of hypotheses, the author developed the Ordinary Least Squares regression model (OLS) as follows:

$$
\begin{gathered}
\mathrm{ACTPOL}=\alpha_{0}+\alpha_{1} \mathrm{LEV}+\alpha_{2} \mathrm{SALE}+\alpha_{3} \mathrm{INC}+\alpha_{4} \mathrm{TAX} \\
+\alpha_{5} \mathrm{ACT}+\alpha_{6} \mathrm{AUD}+\varepsilon
\end{gathered}
$$

\section{Independent variables:}

SALE: Company size is measured by the revenue collected from the annual financial statements.

LEV: Leverage ratio is measured by the ratio of total long-term debt to with total book value of equity, both collected at the end of the financial year.
INC: The incentive plan is determined by announcement of the company's incentive plan in the annual financial statements. Label 1 if the company has an incentive plan; label 0 if the company does not have an incentive plan.

TAX: To be determined based on the payable enterprise income tax amount in the financial statements.

AUD: Auditors, it takes 1 if the SME performs annual audits; take 0 if the SME does not perform an audit.

ACT: Accountant knowledge, it takes 1 if the accountant has a university or graduated degree; and it chooses 0 if the accountant has a college or intermediate degree

\section{Dependent variables:}

ACTPOL: the percentage of income-decreasing accounting procedures (income-decreasing accounting policies to total choices of accounting policies). Various authors (for instance, Waweru, Ntui, Mangena, 2011) have summarized how the selection of accounting policies affect the income and they are displayed in Table 1.

\subsection{Data}

Research data was collected from the questionnaire sent to accountants and chief accountants of SMEs in Vietnam. In accordance with the objectives of the research, the questionnaire was sub-divided into 3 sections. The first section solicited information about respondents' profile. This was done to determine demographic background information about the respondents. The second section contained questions pertaining to the Vietnamese SMEs being surveyed such as the location of the business, nature of business, number of employees appointed, etc. And the third section solicited responses concerning factors influencing the choices of accounting policies in SMEs in Vietnam. There were 250 questionaires sent to respondents and we collected 200 responds. According to Hoang and Chu (2013) the sample size of 200 responses from non-financial companies is representative for the whole population.

After collecting company data and calculating research variables, the data is processed through the following steps:

Table 1: Choices of accounting policies affecting profit strategy

\begin{tabular}{|l|l|l|}
\hline Accounting policies & \multicolumn{1}{|c|}{ Increase income } & \multicolumn{1}{|c|}{ Decrease income } \\
\hline Depreciation methods & Straight-line & Diminishing value method \\
\hline Inventory-costing methods & Fist in - first out & Weighted average \\
\hline Provision for obsolete inventory & Make no provision & Make provision \\
\hline Provision for bad debts & Make no provision & Make provision \\
\hline Provision for devaluation of financial investment & Make no provision & Make provision \\
\hline Sales policy & Make provision & Make no provision \\
\hline
\end{tabular}


- Step 1: Conduct statistical description to understand the basic characteristics of the data collected through the average values, median values, maximum values, minimum values, and standard deviations of the variables in the model.

- Step 2: Analyze the correlation between independent variables.

- Step 3: Verify the compliance of regression assumptions

- Step 4: Check the reliability of the variables.

- Step 5: Perform regression analysis according to the research model given by the OLS.

\section{Research Results}

The research result for above 5 steps is presented in Table 2:

From Table 3, it is shown that all variables have an impact on the Accounting-policy choice (ACTPOL) variable with significant level of 1 percent. ACTPOL is inversely related to the audittors (AUD), meanwhile other variables have positive impact on ACTPOL with significance level of $5 \%$. The Pearson Correlation coefficient also indicate that there is no existing autocorrelation and multicoleanity phenomenon in the research model.

Table 2: Descriptive Statistics for research variables

\begin{tabular}{|l|c|c|c|c|c|}
\hline & N & Minimum & Maximum & Mean & Std. Deviation \\
\hline \% income-changing procedures & 200 & .167 & 1.000 & .644 & .234 \\
\hline Revenue (VND 1,000,000) & 200 & 17.394 & 73.648 & 36.204 & 74.704 \\
\hline Financial leverage (times) & 200 & .000 & 60 & 2.15 & 4.59 \\
\hline Tax (VND 1,000) & 200 & .00 & 3.598 .173 & 90.514 & 297.280 \\
\hline Valid N (listwise) & 200 & & & & \\
\hline
\end{tabular}

Table 3: Result of correlation analysis

\begin{tabular}{|c|c|c|c|c|c|c|c|c|}
\hline & & ACTPOL & SALE & LEV & TAX & AUD & INC & $\mathrm{ACT}$ \\
\hline \multirow{3}{*}{ ACTPOL } & Pearson Correlation & 1 & $.646^{* *}$ & $.421^{* *}$ & $.322^{* *}$ & $-.589^{* *}$ & $.213^{* *}$ & $.333^{* *}$ \\
\hline & Sig. (2-tailed) & & .000 & .000 & .000 & .000 & .002 & .000 \\
\hline & $N$ & 200 & 200 & 200 & 200 & 200 & 200 & 200 \\
\hline \multirow{3}{*}{ SALE } & Pearson Correlation & $.646^{* *}$ & 1 & $.499^{* *}$ & -.001 & $-.327^{\star \star}$ & $.291^{\star *}$ & $.162^{*}$ \\
\hline & Sig. (2-tailed) & .000 & & .000 & .988 & .000 & .000 & .022 \\
\hline & $N$ & 200 & 200 & 200 & 200 & 200 & 200 & 200 \\
\hline \multirow{3}{*}{ LEV } & Pearson Correlation & $.421^{* *}$ & $.499^{* *}$ & 1 & $.228^{* *}$ & $-.376^{* *}$ & .083 & .031 \\
\hline & Sig. (2-tailed) & .000 & .000 & & .001 & .000 & .245 & .664 \\
\hline & $\mathrm{N}$ & 200 & 200 & 200 & 200 & 200 & 200 & 200 \\
\hline \multirow{3}{*}{ TAX } & Pearson Correlation & $.322^{* *}$ & -.001 & $.228^{* *}$ & 1 & -.130 & -.036 & $.170^{*}$ \\
\hline & Sig. (2-tailed) & .000 & .988 & .001 & & .067 & .617 & .016 \\
\hline & $N$ & 200 & 200 & 200 & 200 & 200 & 200 & 200 \\
\hline \multirow{3}{*}{ AUD } & Pearson Correlation & $-.589^{* *}$ & $-.327^{\star *}$ & $-.376^{* *}$ & -.130 & 1 & -.107 & -.083 \\
\hline & Sig. (2-tailed) & .000 & .000 & .000 & .067 & & .132 & .243 \\
\hline & $\mathrm{N}$ & 200 & 200 & 200 & 200 & 200 & 200 & 200 \\
\hline \multirow{3}{*}{ INC } & Pearson Correlation & $.213^{* *}$ & $.291^{\star *}$ & .083 & -.036 & -.107 & 1 & .122 \\
\hline & Sig. (2-tailed) & .002 & .000 & .245 & .617 & .132 & & .085 \\
\hline & $\mathrm{N}$ & 200 & 200 & 200 & 200 & 200 & 200 & 200 \\
\hline \multirow{3}{*}{$\mathrm{ACT}$} & Pearson Correlation & $.333^{* *}$ & $.162^{*}$ & .031 & $.170^{*}$ & -.083 & .122 & 1 \\
\hline & Sig. (2-tailed) & .000 & .022 & .664 & .016 & .243 & .085 & \\
\hline & $\mathrm{N}$ & 200 & 200 & 200 & 200 & 200 & 200 & 200 \\
\hline
\end{tabular}


Table 4: Regression results for the model

\begin{tabular}{|c|c|c|c|c|c|c|c|}
\hline \multirow{2}{*}{ Model } & \multicolumn{2}{|c|}{$\begin{array}{l}\text { Unstandardized } \\
\text { Coefficients }\end{array}$} & \multirow{2}{*}{$\begin{array}{c}\text { Standardized } \\
\text { Coefficients } \\
\text { Beta } \\
\end{array}$} & \multirow{2}{*}{$\mathbf{t}$} & \multirow{2}{*}{ Sig. } & \multicolumn{2}{|c|}{ Collinearity Statistics } \\
\hline & B & Std. Error & & & & Tolerance & VIF \\
\hline (Constant) & -1.860 & .319 & & -5.837 & .000 & & \\
\hline SALE & .079 & .010 & .463 & 7.660 & .000 & .582 & 1.717 \\
\hline TAX & .017 & .003 & .259 & 5.450 & .000 & .941 & 1.063 \\
\hline AUD & -.130 & .032 & -.248 & -4.126 & .000 & .587 & 1.702 \\
\hline ACT & .094 & .024 & .188 & 3.943 & .000 & .940 & 1.064 \\
\hline
\end{tabular}

The independent variables will have multi-collinear phenomena when the Tolerance coefficient is less than 0.1 or VIF is greater than 10. In Table 4, the value of the Tolerance coefficient of the independent variables are greater than 0.1 . VIF values of variable are all less than 10 . This evidence shows that there is no multicollinearity phenomenon between variables. The model of analyzing the factors influencing income-increasing accounting policies is as follows:

$$
\begin{aligned}
\mathrm{ACTPOL}=-1,86 & +0.463 \mathrm{SALE}+0.259 \mathrm{TAX}-0.48 \mathrm{AUD} \\
& +0.188 \mathrm{ACT}
\end{aligned}
$$

Table 4 shows that the adjusted $\mathrm{R}^{2}$ of the model is 0.583 , which means that the model explains $58,3 \%$ of the factors influencing the income-reducing accounting procedures. Research shows that the company size is a factor explaining the choice of accounting policies, so the hypothesis $\mathrm{H}_{1}$ is supported. This is consistent with studies of Waweru, Ntui, Mangena (2011) and Pham and Nguyen (2019). With the goal of reducing the payable tax amount, the manager will choose the accounting policy which reduces profits, the hypothesis $\mathrm{H}_{5}$ is supported. Businesses that are customers of auditing firms often choose accounting policies to increase profits, the hypothesis $\mathrm{H}_{4}$ is supported. This is consistent with studies of Takada \& Muramiya (2013). The higher the level of accountants, businesses will choose accounting policies to reduce profits, and the hypothesis H6 is supported.

\section{Conclusion}

This paper aimed at investigating factors affecting selection of accounting policies of managers in 200 SMEs in Vietnam. The author examined 6 factors: Company size; Leverage; Auditors; Incentive plans; Tax; and Accountant which may impact managers' selection of accounting policies in Vietnamses SMEs. The results shows that four factors influence selection of accounting policies in which
Auditors are associated with income-increasing accounting policies; and there are three factors associating with incomedecreasing accounting policies including company size, tax and accountant. Among 4 influential factors, company size has the most significant impact (the Beta coefficient is $0.463)$.

The research results show that SMEs often choose income decreasing accounting policies so that the SMEs could lower their corporate tax. The smaller the size of enterprises, more limited is the accounting work at each unit and it is more likely to make mistakes. In order to create a real change in accounting work in the SMEs, it is necessary to have active intervention from the authorities, the continuous efforts from businesses to improve the role and quality of accounting work as well as creating sustainable development. Upon the results we propose the following instructive suggestions:

First, it is necessary to carry out a number of solutions to improve the accounting system of the enterprise in the direction of solving the most common accounting issues which is simple and feasible for accounting work in SMEs. Solutions are required to raise awareness of the management board. This leads to enhancement in the activities of accounting professional organizations, developing accounting consulting services and financial reporting consulting services.

Second, for the businesses, it is necessary to build an accounting apparatus which is suitable to the management structure of the enterprise. Firms should select accounting personnel according to the requiremet of each position and in accordance with professional, financial and accounting regimes. Information technology should be used in the processing of accounting data which will ensure accuracy and timeliness.

Third, government should improve tax policies in relation to corporate income tax. In addition, the tax enforcement should be more strengthened so that the fraud activities of SMEs could be prevented. 
Next, it is necessary to develop a separate accounting standard for small and medium enterprises in the current time period which will contribute in completion of the legal framework of accounting systems in Vietnam, in accordance with the requirements of domestic economic development and in harmony with the prevailing international accounting practices. In addition, the government should set sanctions for SMEs which do not comply with regulations on accounting, finance and tax issues.

And the last but not least, for the auditing companies, it is important to emphasize the importance of getting to know customers (SMEs) when starting an audit. This provides useful information that helps in the judgement of the customers' motives, thereby knowing their tendency to adjust their profits (increase or decrease profits) by choosing an accounting policy, therefore there is a need to design appropriate audit procedures.

Overall, the research scope of the topic is limited because the topic focusses only on non-financial companies in Vietnam. In addition, the research sample of the topic has used company pooling from many different industries. Apart from this, in the research sample, the topic used is only relevant for small and medium-sized enterprises, not for the big enterprises. And finally, the research focuses only on 6 independent variables. In fact, there are many more variables that can affect the choice of accounting policies of enterprises such as debt covenants, financial risk, etc. We see that these limitations will lead to potential future researches.

\section{References}

Aitken, M. J., \& Loftus, J. A. (2009). Determinants of accounting policy choice in the Australian property industry: A portfolio approach, Journal of Accounting and Finance, 34(2), 1-20, https://doi.org/10.1111/j.1467-629X.1994.tb00266.x

Astami, W. E., \& Tower, G. (2006). Accounting - Policy Choice and Firm Characteristics in the Asia Pacific Region: An International Empirical Test of Costly Contracting Theory. The International Journal of Accounting, 41(1), 1-21. https:// doi.org/10.1016/j.intacc.2005.12.004

Astuti, R. N., Fachrurrozie, F., Amal, M. I., \& Zahra, S. F. (2019). Does Audit Committee Quality Mediate Determinants of Intellectual Capital Disclosure? Journal of Asian Finance, Economics and Business, 7(7), 199-208. doi:10.13106/ jafeb.2020.vol7.no7.199

Bhattacharya, U., Daouk, H., \& Welker, M. (2003). The World Price of Earnings Opacity. The Accounting Review, Available at SSRN: https://ssrn.com/abstract $=368920$

Beattie, V., Stephen, B., David, E., Brian, J., Stuart, M., Dylan, T., \& Turner, M. (1994). Extraordinary items and income smoothing: A positive accounting approach. Journal of Business Finance \& Accounting, 21(6), 791-811.
Bitner, L. N., \& Dolan, R. C. (1996). Assessing the relationship between income smoothing and the value of the firm. Quarterly Journal of Business and Economics, 35, 16-35.

Bowen, R. M., \& Shores, D. (1995). Stakeholders' implicit claims and accounting method choice. Journal of Accounting and Economics, 20, 255-295.https://doi.org/10.1016/0165-4101(95) 00404-1

Collings, S. (2010). The Interpretation and Application of International Standards on Auditing. Manchester: UK: Wiley.

Cotter, J. (1999). Asset Revaluations and Debt Contracting. Abacus, $35,268-285$.

Cullinan, C., \& Knoblett, J (1994). Unionization and accounting policy choices: An empirical examination. Journal of Accounting and Public Policy, 13, 49-78.

Cullinan, P. C. (1999). International trade and accounting policy choice: Theory and Canadian evidence. The International Journal of Accounting, 34(4), 597-607. https://doi.org/10.1016/ S0020-7063(99)00022-9

DeAngelo, L. E. (1981). Auditor size and audit quality. Journal of Accounting and Economics, 3(3), 183-199.

DeAngelo, H., DeAngelo, L., \& Skinner, D. J. (1994). Accounting choice in troubled companies. Journal of Accounting and Economics, 17, 113-143.

Dechow, P. M. (1994). Accounting earnings and cash flows as measures of firm performance: The role of accounting accruals. Journal of Accounting and Economics, 18(1), 3-42. https://doi. org/10.1016/0165-4101(94)90016-7

Do, D. T., Nguyen, T. H., Nguyen, T. H. N., Ha, H. H., \& Le, T. T. (2020). The Influence of Leadership Style on Accountants' Commitment with Enterprise: An Empirical Study on Vietnamese FDI Firms. Journal of Asian Finance, Economics and Business, 7(3), 235-243. doi:10.13106/jafeb.2020.vol7. no3.235.

Fekete, S., Damagum, Y. M., Mustata, R. M., Dumitru Matis D., \& Popa, A. (2010). Explaining Accounting Policy Choices of SME's: An Empirical Research on the Evaluation Methods. European Research Studies, 13(1), 33-48.

Francis, J. R., Maydew, E. L., \& Sparks, H. C. (1999). The Role of Big 6 Auditors in the Credible Reporting of Accruals. Auditing. A Journal of Practice and Theory, 18(2), 17-34. https://doi. org/10.2308/aud.1999.18.2.17

Freeman, R. E. (1984). Strategic Management: A Stakeholder Approach. Boston, MA: Pitman.

Hagerman, R. L., \& Zmijewski, M. E. (1979). Some economic determinants of accounting policy choice. Journal of Accounting and Economics, 1(2), 141-161.

Hagerman, R., \& Zmijewski, M. (1981). An income strategy approach to the positive theory of accounting standard setting/choice. Journal of Accounting and Economics, 3(2), 129-149. https://doi.org/10.1016/0165-4101(81)90010-0. 
Hoang, T., \& Chu, N. M. N. (2013). Applied Statistics in SocioEconomic Research. Hanoi, Vietnam: Statistical Publisher.

Jensen, M. C., \& Meckling W. H. (1976). Theory of the Firm: Management behavior, agency costs and ownership structure. Journal of Financial Economics, 3(4), 305-360.

Inoue, T., \& Thomas, W. (1996). The choice of accounting policy in Japan. Journal of International Financial Management and Accounting, 7(1), 1-48. https://doi.org/10.1111/j.1467646X.1996.tb00061.x

Islam, M. A., \& Deegan, C. (2010). Media pressures and corporate disclosure of social responsibility performance information: A study of two global clothing and sports retail companies. Accounting and Business Research, 40(2), 131-148. doi: https:// doi.org/10.1080/00014788.2010.9663388

Kenneth, L. W., \& Michael, J. P. (1992). Economic determinants of accounting policy choice: The case of current cost accounting in the UK. Journal of Accounting and Economics, 15(1), 87114. https://doi.org/10.1016/0165-4101(92)90013-R

Kim, H. S., \& Cho, K. S. (2020). The Determinants of Blockholder Presence: Evidence from Korea. Journal of Asian Finance, Economics and Business, 7(4), 29-39. doi:10.13106/ jafeb.2020.vol7.no4.29

Missonier-Piera, F. (2004). Economic Determinants of Multiple Accounting Method Choices in a Swiss Context. Journal of International Financial Management and Accounting, 15(2), 118-144. https://doi.org/10.1111/j.1467-646X.2004.00104.x

Nguyen, T. P. H., \& Nguyen, T. K. O. (2014). Factors affecting the selection of accounting policies in Vietnamese enterprises, Journal of Market - Finance - Monetary, 13(7) (Vietnamese).

Okpala, K. E. (2016). Factors influencing accounting policy choices under IFRS in Airline-GSA companies. Ilorin Journal of Accounting, 2(2), 1-12.

Pham, D. C., \& Nguyen, T. X. H. (2019). The influence of privatization on financial performance of Vietnamese privatized state-owned enterprises. Investment Management and Financial Innovations, 16(3), 341-352. doi:10.21511/ imfi.16(3).2019.30

Rahman, Z., \& Scapens, R. W. (1988). Financial reporting by Multinational Enterprises: Accounting policy choice in a developing country. Journal of Accounting and Public Policy, 7(1), 29-42. https://doi.org/10.1016/0278-4254(88)90003-8

Rountree, B., Weston, J. P., \& GeorgeAllayannis, G. (2008). Do investors value smooth performance? Journal of Financial Economics, 90(3), 237-251.

Raffournier, B. (1995). The Determinants of Voluntary Financial Disclosure by Swiss Listed Companies. The European Accounting Review, 4, 261-280. https://doi.org/10.1080/09638189500000016

Ross, S. (1977). The Determination of Financial Structure: The Incentive Signaling Approach. The Bell Journal of Economics, 8(1), 23-40. doi: 10.2307/3003485

Spence, M. (1973). Job Market Signaling. The Quarterly Journal of Economics, 87(3), 355-374. DOI: 10.2307/1882010.

Sutton, R. (1988). Learning to Predict by the Method of Temporal Differences. Machine Learning, 3(1), 9-44. DOI: 10.1007/ BF00115009

Tawfik, M. S. (2015). An Empirical Investigation of the validity of the Positive Theory in Developing Countries: The Case of the Kingdom of Saudi Arabia. SSRN Electronic Journal. DOI: 10.2139/ssrn.2601673.

Takada, T., \& Muramiya, K. (2013). The Analysis on Big 4 Auditor Conservatism. Journal of Ecnomics and Business Administration, 208(5), 53-68.

Tzovas, C. (2006). Factors influencing a firm's accounting policy decisions when tax accounting and financial accounting coincide. Managerial Auditing Journal, 21(4), 372-386. DOI: 10.1108/02686900610661397

Watts, R. L., \& Zimmerman, J. L. (1986). Positive accounting theory. Englewood Cliffs, NJ: Prentice-Hall.

Watts. R., \& Zimmerman, J. (1978). Towards a positive theory of the determination of accounting standards. Accounting Review, 53(1), 112-134. https://www.jstor.org/stable/245729.

Waweru, N. M. Ntui, P. P., \& Mangena, M. (2011). Determinants of different accounting methods choice in Tanzania: A positive accounting theory approach. Journal of Accounting in Emerging Economies, 1(2), 144-159. https://doi. org/10.1108/20421161111138503 